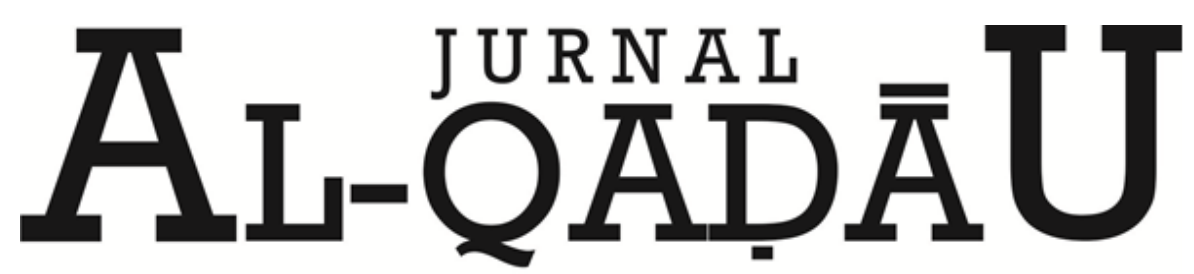

PERADILAN dan HUKUM KELUARGA ISLAM

\title{
Tinjauan Hukum Islam terhadap Perlindungan Hukum Narapidana Wanita Dalam Sistem Pemsyarakatan (Studi Kasus Lembaga Pemasyarakatan Kelas IIA Watampone)
}

The Overview of Islamic Law towards Female Prisoners In Prison System (Case Study of

Classroom IIA Watampone)

Marwan Fadhel Madjid

Pascasarjana UIN Alauddin Makassar

Email: Fadhelmarwanmajid@gmail.com

\begin{tabular}{|c|c|}
\hline $\begin{array}{c}\text { Info } \\
\text { Artikel }\end{array}$ & Abstract \\
\hline $\begin{array}{l}\text { Diterima } \\
28 \\
\text { Februari } \\
2018\end{array}$ & $\begin{array}{l}\text { Hasil Penelitian ini menjelaskan subtansi hak-hak hukum narapidana } \\
\text { wanita dalam lapas kelas IIA terimplementasi dalam Undang-Undang } \\
\text { Nomor } 12 \text { tahun } 1995 \text { tentang Pemasyarakatan, PERMENKUMHAM } \\
\text { Nomor } 33 \text { Tahun } 2015 \text { tentang pengamanan pada lembaga } \\
\text { pemasyarakatan dan rumah tahanan, serta Keputusan Menteri } \\
\text { Kehakiman Republik Indonesia No.M.O2-PK.04.10 Tahun 1990. Dalam } \\
\text { mewujudkan perlindungan hukum hak-hak narapidana wanita telah } \\
\text { menyediakan fasilitas keamanan, kesehatan, keterampilan, dan spiritual } \\
\text { serta pegawai wanita dalam memberikan pelayanan kepada narapidana } \\
\text { wanita. Kondisi narapidana wanita menunjukkan sikap dan perilaku yang } \\
\text { cukup berintegritas dan beradab yang dibuktikan dengan sikap kejujuran, } \\
\text { konsisten dan komitmen oleh para narapidana wanita sehingga rasa } \\
\text { kebersamaan di antara sesama napi wanita di lapas kelas IIA Watampone } \\
\text { terjalin dengan baik. Rasa kebersamaan ini, dapat disaksikan saat napi } \\
\text { membersihkan blok lapas secara gotong royong. }\end{array}$ \\
\hline
\end{tabular}

Revisi II

30

April

2018

\section{Disetujui}

24

Mei

2018
Kata kunci: Perlindungan hukum, Narapidana wanita, Sistem pemasyarakatan

The results of this study describe the substance of women prisoners' legal rights in prisons IIA implemented in Law No. 12 of 1995 on Corrections, PERMENKUMHAM No. 33 of 2015 on security in prisons and prisons, and Decree of the Minister of Justice of the Republic of Indonesia No.M $.02-P K .04 .10$ In 1990. In realizing the legal protection of women's inmates' rights have provided security, health, skills and spiritual facilities and female employees in providing services to female prisoners. The condition of female prisoners shows attitudes and behaviors that are quite integrity and civilized as evidenced by the attitude of honesty, consistency and commitment by the female prisoners so that the sense of togetherness among fellow prison women in prison class Iia Watampone wellestablished. This sense of togetherness can be witnessed when the prisoner clears the prison block in mutual assistance.

Keywords: Legal protection, female prisoners, correctional system 


\section{A. PENDAHULUAN}

Bagi umat Islam setiap hak harus dikembalikan kepada dua sumber rujukannya yaitu Alquran dan Sunnah. Jadi hak asasi manusia (HAM) menemukan landasan yang kuat dalam hukum Islam. Dalam Islam pula, semakin manusia tunduk kepada Tuhan dan hanya mengabdi kepadaNya, semakin bebas ia dari penghambaan kepada manusia lain atau ciptaan Tuhan lainnya. Dengan menyatakan Allahu Akbar (Allah Maha Besar) ia menutup pintu dari semua penghambaan. Hal tersebut berarti menegaskan bahwa pada dasarnya dirinya bebas. Dalam hukum Islam hak-hak fundamental tidak diciptakan oleh manusiamelainkan, hanya dibuat menjadi terang. Hak-hak tersebut diturunkan secara tidak langsung dari nilai daasrnya bahwa, ia adalah hamba Tuhan, tidak menghamba kepada yang lain. ${ }^{1}$

Al-Qardhawy memeberikan pandangan bahwa wanita memiliki hak yang sama dengan pria dari segi kemanusiaan. Mereka sama dalam masalah pertumbuhannya, sama dalam masalah kekhususan-kekhususan kemanusiaan secara umum, sama dalam masalah menjalankan perintah dan larangan dalam syari'at, sama dalam masalah tanggung jawab dan sama dalam masalah balasan serta tempat kembali. ${ }^{2}$

Sejak lebih 1400 tahun lampau, hak-hak tertentu telah mendapat jaminan berdasarkan Alquran yaitu: hak hidup, keamanan diri, kemerdekaan, perlakuan yang sama, kemerdekaan berpikir dan berekspresi, keyakinan dan beribadah, perkawinan, keemrdekaan hukum, asas praduga tak bersalah, perlindungan dari kekejaman, suaka,

${ }^{1}$ Topo Santoso, Asas-Asas Hukum Pidana Islam (Cet 1, Jakarta: PT Rajagrafindo Persada, 2016), h. 196

${ }^{2}$ Yusuf al-Qardhawy, Ruang Lingkup Aktivitas Wanita Muslimah, terj.Moh. Suri Sudari A, Entin Rani'ah Ramelan (Jakarta: Pustaka al-Kautsar, 1996), h 19-20. 
kebebasan berserikat dan berkumpul, berprofesi, hak memilih, memperoleh dan menentukan hak milik. Alquran memberi tekanan pada persamaan diantara manusia. Semua manusia adalah sama dalam hal spiritual mereka, karena telah diciptakan oleh pencipta yang sama, mereka sama dalam asal fisik karena berasal dari spesies yang sama. Tidak ada ruang bagi klaim superiotas karena asal atau nenek moyang.

Islam tidak mengakui keutamaan atas dasar kelahiran, kebangsaan atau faktorfaktor lain. Kemuliaan yang sesungguhnya terletak pada ketakwaan semata-mata. Rasulullah saw. bersabda: semua manusia adalah sama seperti gigi sisir. Bangsa Arab tidak lebih tinggi dibanding bangsa lainnya kecuali ketakwaan. ${ }^{3}$

Menurut Quraish Shihab, persamaan antara laki-laki dan perempuan baik laki-laki maupun perempuan, juga persamaan antar bangsa, suku, dan keturunan, adalah pokok ajaran dan prinsip utama dalam ajaran Islam, dalam al-Quran Allah swt berfirman dalam QS. al-Hujurat/49:13:

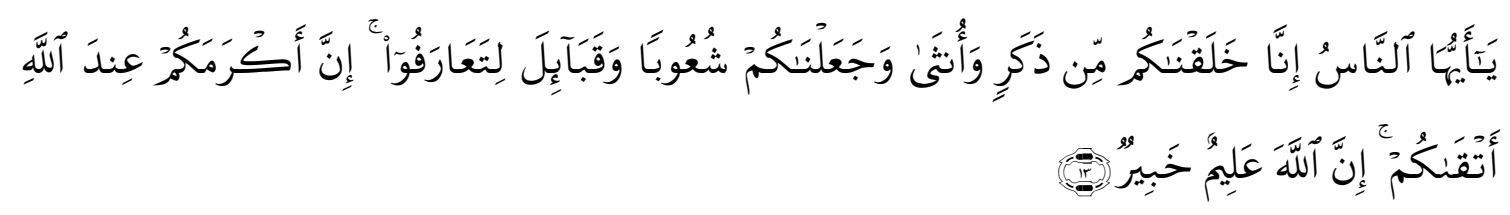

Terjemahannya:

"Wahai seluruh manusia, sesungguhnya Kami menciptakan kamu (terdiri) dari laki-laki dan perempuan, dan Kami jadikan kamu bebangsa-bangsa dan bersukusuku agar kamu saling mengenal. Sesungguhnya yang paling mulia diantara kamu adalah yang paling bertakwa." 5

Kedudukan wanita dalam hukum Indonesia tergambar melalui Pasal 28 UUDNRI Tahun 1945 yang berisikan kaidah-kaidah umum tentang kesetaraan antara laki-laki dan wanita. Undang-Undang Nomor 39 tahun 1999 tentang Hak Asasi Manusia (HAM) secara eksplisif mengatur hak-hak wanita yaitu bagian kesembilan pada Pasal 45 sampai dengan Pasal 51. Muatan perlindungan hak-hak tersebut antara lain : hak wanita adalah bagian dari HAM (Pasal 45), pengakuan hak politik wanita (Pasal 46), Hak wanita atas kewarganegaraan (Pasal 47), hak wanita atas pendidikan dan pengajaran (Pasal 48), hak wanita atas pekerjaan (Pasal 49), hak wanita atas kesehatan reproduksi (Pasal 49), hak wanita atas perbuatan hukum yang mandiri (pasal 50), dan hak wanita dalam perkawinan, perceraian dan pengasuhan anak (Pasal 51). Sementara ini tengah hadir produk hukum lain yang secara jelas melindungi kedudukan wanita dan merupakan buah perjuangan dari gerakan-gerakan wanita Indonesia adalah Undang-Undang Nomor 23 tahun 2004 tentang Penghapusan Kekerasan Dalam Rumah Tangga. ${ }^{6}$

Secara filosofis Pemasyarakatan adalah sistem pemidanaan yang sudah jauh bergerak meninggalkan filosofi retributif (pembalasan), dan deterrence

\footnotetext{
${ }^{3}$ Topo Santoso, Asas-Asas Hukum Pidana Islam, h. 197.

${ }^{4}$ Atik Wartini, "Tsafsir Feminis M.Quraish Shihab Telaah: Ayat-Ayat Gender dalam Tafsir alMisbah", PALASTREN6, No. 2, ([t.t],[t.p],2013), h. 486.

${ }^{5}$ Kementrian Agama RI, Al-Qur'an dan Terjemahanya (Bandung: Syamil Qur'an,2009),h. 517. 215.

${ }^{6}$ Sri Widoyati Wiratmo Soekito, Anak dan Wanita dalam Hukum, (Jakarta: LP3ES, 1983), h.
} 
(penjeraan).Dengan kondis demikian, pemidanaan tidak ditujukan untuk menyiksa atau membuat derita sebagai bentuk pembalasan, juga tidak mengasumsikan terpidana sebagai seseorang yang kurang sosialisasinya.Pemasyarakatan sejalan dengan filosofi reintegrasi sosial yang berasumsi kejahatan adalah konflik yang terjadi antara terpidana dengan masyarakat, sehingga pemidanaan ditujukan untuk menyatukan kembali terpidana dengan masyarakatnya (reintegrasi). ${ }^{7}$

Narapidana mempunyai hak-hak yang harus dilindungi dan diayomi. Hak antara narapidana pria, narapidana wanita dan narapidana anak berbeda-beda.Dalam hal ini masing-masing narapidana harus ada yang dikedepankan. Sudah menjadi kodrat wanita mengalami siklus menstruasi, hamil, melahirkan dan menyusui yang tidak dipunyai oleh narapidana lain, sehingga sudah menjadi suatu kewajaran bahwa narapidana wanita mempunyai hak-hak khusus dibandingkan dengan narapidana lain.

Bila melihat ketentuan yang diatur dalam Undang-Undang No. 12 tahun 1995 tentang Pemasyarakatan, ternyata masalah narapidana wanita tidak ada pengaturannya. Karena yang disebutkan hanya narapidana tidak dibedakan antara narapidana laki-laki maupun wanita, ini berarti telah terjadi kekosongan norma, sehingga kedepan hal ini perlu mendapat pengaturan norma antara narapidana laki-laki dan wanita tidak bisa diperlakukan sama, mengingat perbedaan pisik dan psikologis laki-laki dan wanita. Untuk melaksanakan ketentuan Pasal 14 Undang-Undang No. 12 tahun 1995 tentang Pemasyarakatan ditetapkan Peraturan Pemerintah Nomor: 32 Tahun 1999, tentang Syarat dan Tata Cara Pelaksanaan Hak Warga Binaan Pemasyarakatan. Pasal 20 Peraturan Pemerintah Nomor: 32 Tahun 1999, memuat perlindungan terhadap narapidana wanita yaitu:

1. Narapidana dan Anak didik pemasyarakatan yang sakit, hamil dan menyusui berhak mendapat makanan tambahan sesuai dengan petunjuk dokter;

2. Makanan tambahan juga diberikan kepada narapidana yang melakukan jenis pekerjaan tertentu;

3. Anak dari narapidana wanita yang dibawa ke dalam LAPAS ataupun yang lahir di LAPAS dapat diberi makanan tambahan atas petunjuk dokter, paling lama sampai berumur 2 (dua) tahun;

4. Dalam hal anak sebagaimana dimaksud dalam ayat 3 telah mencapai umur 2 (dua) tahun, harus diserahkan kepada bapaknya atau sanak keluarga, atau pihak lain atas persetujuan ibunya dan dibuat dalam satu berita acara;

5. Untuk kepentingan kesehatan anak, Kepala LAPAS dapat menentukan makanan tambahan selain sebagaimana di maksud dalam ayat 3 berdasarkan pertimbangan. ${ }^{8}$

Perkembangan tindak pidana yang dilakukan narapidana wanita dari tahun ketahun berpariasi jumlahnya untuk mengatasinya disinilah dituntut kesadaran hukum masyarakat khususnya bagi wanita, artinya ketiga unsur dalam proses pemasyarakatan antara narapidana, petugas pemasyarakatan dan masyarakat harus saling mendukung.

${ }^{7}$ Tim Direktorat Jenderal Pemasyarakatan, Cetak Biru Pembaharuan Pelaksanaan Sistem Pemasyarakatan (Jakarta: Dirjen Pemasyarakatan, 2008), h. 5.

${ }^{8}$ Republik Indonesia, Peraturan Pemerintah Nomor: 32 Tahun 1999, Tentang Syarat dan Tata Cara Pelaksanaan Hak Warga Binaan Pemasyarakatan, Pasal 20. 
Dari uraian di atas, maka permasalahan yang dalam pembahasan tulisan ini adalah Bagaimana Tinjaun Hukum Islam Terhadap Perlindungan Hukum Narapidana Wanita dalam SistemPemasyarakatan (Studi Kasus Lapas Kelas IIA Watampone),?

\section{B. METODE PENELITIAN}

Jenis penelitian yang digunakan pada penelitian ini adalah penelitian lapangan (field research) yang berusaha meneliti atau melakukan studi terhadap realita kehidupan sosial. ${ }^{9}$ Penelitian ini bersifat deskriptif kualitatif, artinya, penulis menganalisis dan menggambarkan penelitian secara objektif dan mendetail untuk mendapatkan hasil yang akurat.

Pada penelitian ini penulis menggunakan jenis pendekatan yuridsi empiris karena penelitian ini meneliti bagaimana kondisi narapidana wanita selama berada dalam lapas kelas IIA Watampone dan kondisi lapas kelas IIA Watampone dalam memenuhi hak-hak hukum narapidana wanita selama berada di dalam lembaga pemasyarakatan.

Penulisan penelitian ini menggunakan dua macam data, yakni data primer dan data sekunder. Data primer pada penelitian ini adalah hasili wawancara dan respondensi dengan narapidana pira, wanitam dan pihak lapas kelas II A Watampone. Adapun data sekunder biasanya telah disusun dalam bentuk dokumen-dokumen, yakni data yang diperoleh dari literature seperti buku, majalah, dokumen, atau referensi lain yang berkaitan dengan penelitian ini. ${ }^{10}$ Selanjutnya peneliti juga menggunakan bahan hukum tersier merupakan bahan hukum yang dapat memberikan petunjuk dan penjelasan terhadap bahan hukum primer dan sekunder. ${ }^{11}$ Bahan hukum tersier dalam penelitian antara lain, ensiklopedia dan kamus hukum, dan kamus besar bahasa Indonesia. Pengumpulan data dapat dilakukan dengan observasi, wawancara, dokumentasi, dan gabungan keempatnya

\section{PEMBAHASAN}

\section{Subtansi Hak-Hak Hukum Narapidana Wanita Yang Harus Dilindungi dalam Lembaga Pemasyarakatan di Lapas Kelas IIA Watampone}

Hak narapidana wanita adalah sesuatu yang wajib dipenuhi oleh pihak lapas selama narapidana tersebut menjalani masa pidananya. Narapidana wanita memiliki beberapa kebutuhan yang bersifat khusus dan memerlukan perhatian khusus.Hal tersebut harus tetap dipenuhi sekalipun telah berstatus sebagai narapidana.Aturan menganai hak-hak narapidanatermasuk wanitaterdapat di dalamUndang-Undang Nomor 12 tahun 1995 tentang Pemasyarakatan Pasal 14: ${ }^{12}$

Ayat (1):

a. Melakukan ibadah sesuai dengan agama atau kepercayaannya;

b. Mendapat perawatan, baik perawatan rohani maupun jasmani;

\footnotetext{
${ }^{9}$ Suharsimi Arikutno, Prosedur penelitian: Suatu Pendekatan Praktik (Cet. XIII; Jakarta: Rineka Cipta, 2006), h. 9.

${ }^{10}$ Lexy J. Moelong, Metode Penelitian Kualitatif(Cet. XXVII; Bandung: Rosda, 2010), h. 85.

${ }^{11}$ Bambang Soegono, Metodologi Penelitian Hukum (Jakarta: Raja Grafindo Persada, 1992), h. 114. Ayat 1 .

${ }^{12}$ Republik Indonesia, Undang-undang Nomor 12 tahun 1995 Tentang Pemasyarakatan, Pasal 14
} 
c. Mendapatkan pendidikan dan pengajaran;

d. Mendapatkan pelayanan kesehatan dan makanan yang layak;

e. Menyampaikan keluhan;

f. Mendapatkan bahan bacaan dan mengikuti siaran media massa lainnya yang tidak dilarang;

g. Mendapatkan upah atau premi atas pekerjaan yang dilakukan;

h. Menerima kunjungan keluarga, penasihat hukum, atau orang tertentu lainnya;

i. Mendapatkan pengurangan masa pidana (remisi);

j. Mendapatkan kesempatan berasimilasi termasuk cuti mengunjungi keluarga;

k. Mendapatkan pembebasan bersyarat;

1. Mendapatkan cuti menjelang bebas;

m. Mendapatkan hak-hak lain sesuai dengan peraturan perundang-undangan yang berlaku.

Ayat (2):Ketentuan mengenai syarat-syarat dan tata carapelaksanaan hak-hak Narapidana sebagaimana dimaksud dalam ayat (1) diatur lebih lanjut dengan Peraturan Pemerintah. ${ }^{13}$

Pelaksanaan pemenuhan hak-hak narapidana sebagaimanaterdapat dalam Pasal

14 Ayat (1) Narapidana Undang-Undang Nomor 12 Tahun 1995 Tentang Pemasyarakatan di lapas kelas IIA Watampone, dijelaskan dalam 4 (empat) aspek, yakni sebagai berikut:

\section{a) Aspek Keamanan Narapidana Wanita di Lembaga Kelas IIA Watampone}

Aspek keamanan yang maksudkan penulis dalampenulisan ini adalah terjaminya keamanan narapidana selama berada dalam Lapas.Keamanan narapidana telah diatur dalam Undang-Undang No. 12 Tahun 1995 Tentang Pemasyarakatan. Untuk menciptakan keamanan dan menghindari fitnah bagi narapidana wanita tentusaja dibutuhkan adanya pemisahan antara narapidana pria dan wanita.

Menurut pendapat narapidana wanita aktifitas keluar masuk blok tanpa pengamanan dari petugas wanita merupakan salah satu gamabaran minimnya pengamanan bagi narapidana wanita yang ada di lapas kelas IIA Watampone.Guna meminimalisir potensi terjadinya hal-hal yang tidak diingginkan pemerintah telah meregulasikan tentang pembentukan lapas khusus wanita hal ini dijelaskan di dalam pasal 12 ayat 2 UU No. 12 Tahun 1995 tentang Pemasyarakatan.Namun dalam kenyataannya pada lapas kelas IIA Watampone hanya terdapat blok khusus wanita.Secara jelas aspek keamanan narapidana diatur dalam Peraturan Menteri Hukum dan Hak Asasi Manusia (permenkumham) nomor 33 Tahun 2015 tentang Pengamanan pada Lembaga Pemasyarakatan dan Rumah Tahanan Negara.

Pentingnnya kondisi yang aman dalam kehidupan ini juga dijelaskan dalam Islam bahwa kondisi yang aman dapat dicapai dengan menjaga jiwa dari hal-hal yang tidak diinginkan (membahayakan).Menjaga jiwa (hifzhal-nafs) dalam teori maqūssid alSyari'ahdapat diwujudkan dengan mengamalkan sikap-sikap terpuji, yakni menjaga diri dari nafsu yang dapat melecehkan atau menjatuhkan martabat kemanusiaan. Q.S Al An'am/6:82:

\section{Ayat 2.}

\footnotetext{
${ }^{13}$ Republik Indonesia, Undang-undang Nomor 12 tahun 1995 Tentang Pemasyarakatan, Pasal 14
} 


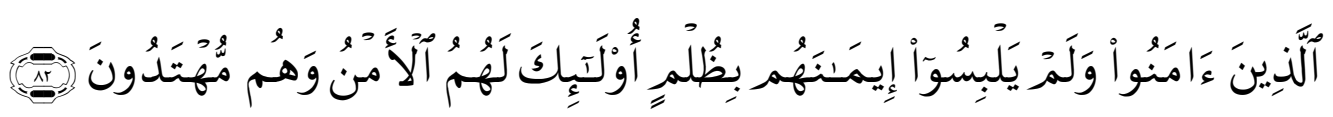

Terjemahnya:

"orang-orang yang beriman dan tidak mencampuradukkan iman mereka dengan kezaliman (syirik), mereka Itulah yang mendapat keamanan dan mereka itu adalah orang-orang yang mendapat petunjuk". ${ }^{14}$

Ayat diatas sebagai jawaban atas pertanyaan tentang golongan mana yang lebih berhak mendapat keamanan. ${ }^{15}$ Keamana yang dimaksud dalam ayat ini adalah pemeberian jaminan bagi siapa saja yang telah mengimani Allah dan Rosulnya. Jaminan keamanan dan keimanan serta hidayah akan diberikan padanya.Seorang muslim dapat melaksanakan amalan sesuai dengan tuntunan petunjuk. Begitu pentingnya, sampaisampai Nabi Ibrahim Alaihissallam memohon kepada Allahswt., curahan keamanan sebelum meminta kemudahan rizki. Sebab orang yang didera rasa takut, tidak akan bisa menikmati lezatnyamakan dan minum. ${ }^{16}$

\section{b) Aspek Kesehatan Narapidana Wanita di Lembaga Kelas IIA Watampone}

Aspek kesehatan yang dimaksudkan dalam penulisan ini adalah terjaminnya kesehatan narapidana wanita selama berada dalam lembaga pemasyarakatan. Memenuhi aspek kesehatan dan mendapatkan makanan yang layak pemerintah telah menetapkannya di dalam UU Nomor 12 Tahun 1995 tentang Pemasyarakatan pada Pasal 14 Ayat 1 huruf (d) .

Keberadaan program pembinaan dibidang kesehatan sangat penting baik berupa program yang kesehatan rohani dan jasmani. Hal tersebut dijelaskan dalam Permen No 32 Tahun 1999 Tentang Syarat dan Tata Cara Pelaksanaan Hak Warga Binaandalam pasal 1 dan 3 yang mengatur tentang penambahan gizi makana bagi narapidana yang hamil dan memiliki balita, pasal 14 sampai pasal18 menjelaskan tentang tatacara pemenuhan hak kesehatan, selajutnya pada pasal 19 sampai 29 menjelaskan tentang tata cara pemenuhan hak mendapatkan makanan yang layak.

Hukum Islam menjelaskan tentang memelihara jiwa sama halnya dengan memilihara kesehatan jiwa dan raga, hal tersebut senada dengan tujuan hukum Islam yang disebut dengan maqūșid al-Syari'ah. Maqōșid al-Syari'ah telah dijelaskan pada bab sebelumnya bahwa tingkat daruriat dalam menjaga jiwa adalah terpenuhinya hajat mendapatkan makanan, pada tingkat hajiat terpenuhinya makan yang halal dan baik, dan pada tingkatan tahsiniat yaitu terpenuhinya makanan ringan sebagai penunjang dan vitamin kesehatan. Hal tersebut juga terdapat di dalam Q.S al Maidah/5: 88

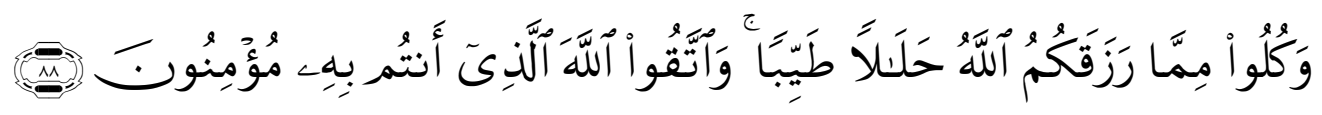

Terjemahnya:

"dan makanlah makanan yang halal lagi baik dari apa yang Allah telah rezekikan kepadamu, dan bertakwalah kepada Allah yang kamu beriman kepada-Nya."17

\footnotetext{
${ }^{14}$ Kementrian Agama RI, Al-Qur'an dan Terjemahanya, h. 82.

${ }^{15}$ M. Quraish Sihab, Tafsir AL-Misbāh Pesan, Kesan dan Keserasian Al-Qur'an, Vol 6,h.524.

${ }^{16}$ M. Quraish Sihab, Tafsir AL-Misbāh Pesan, Kesan dan Keserasian Al-Qur'an, Vol 6,h.526.

${ }^{17}$ Kementrian Agama RI, Al-Qur'an dan Terjemahanya, h. 162.
} 
Ayat ini berbicara menegenai perintah memakan makanan yang halal.Dan makanlah yang halal yakni bukan yang haram lagi baik, lezat, bergizi dan berdampak positif bagi kesehatan.Ayat ini memerintahkan untuk memakan makanan yang halal lagi baik. Tidak semua makanan yang halal sudah tergolong baik karena ada makanan halal baik untuk orang lain namun tidak baik untuk kita karena hal tertentu. Ada makanan yang halal, tetapi tidak bergizi maka pada kondisi seperti ini tergolong tidak baik, sedangkan yang diperintahkan Allah swt., adalah makanan yang halal lagi baik. ${ }^{18}$

\section{c) Aspek Keterampilan Narapidana Wanita di Lembaga Pemasyarakatan Kelas IIA Watampone}

Aspek keterampilan yang dimaksud adalah pendidikan keterampilan yang diberikan kepada narapidana wanita terlaksana dengan efektif selama berada dalam lembaga pemasyarakatan.Pembinaan dibidang keterampilan yang diberikan harus disesuaikan dengan minat dan bakat dari narapidana.Pembinaan keterampilan dengan menghadirkan tegana ahli dan menjalin kerjasama dengan instansi pemerintahan, yayasan, atau lemabga kemasyarakatan yang memiliki orientasi di bindang pembinaan keterampilan pengembangan jenis-jenis pelatihan keterampilan yang sesuai dengan kodisi zaman juga harus terpenuhi.

Pembinaan dibidang keterampilan ini di atur dalam Bab VII angka 2 Keputusan Menteri Kehakiman Republik Indonesia No. M. 02-PK.04.10 Tahun 1990:

2. Pembinaan Kemandirian.

Pembinaan Kemandirian diberikan melalui program-program :

a. Ketrampilan untuk mendukung usaha-usaha mandiri, misalnya kerajinan tangan, industri, rumahtangga, reparasi mesin dan alat-alat elektronika dan sebagainya.

b. Ketrampilan untuk mendukung usaha-usaha industri kecil, misalnya pengelolaan bahan mentah darisektor pertanian dan bahan alam menjadi bahan setengah jadi dan jadi (contoh mengolah rotanmenjadi perabotan rumah tangga, pengolahan makanan ringan berikut pengawetannya danpembuatan batu bata, genteng, batako).

c. Ketrampilan yang dikembangkan sesuai dengan bakatnya masing-masing. Dalam hal ini bagi mereka yang memiliki bakat tertentu diusahakan pengembangan bakatnya itu.Misalnya memiliki kemampuan di bidang seni, maka diusahakan untuk disalurkan ke perkumpulanperkumpulanseniman untuk dapat mengem-bangkan bakatnya sekaligus mendapatkan nafkah.

d. Ketrampilan untuk mendukung usaha-usaha industri atau kegiatan pertanian (perkebunan) denganmenggunakan teknologi madya atau teknologi tinggi, misalnya industri kulit, industri pembuatansepatu kualitas ekspor, pabrik tekstil, industri minyak atsiri dan usaha tambak udang. ${ }^{19}$

Aspek keterampilan yang menjadi salah satu unsur penting dalam memenuhi hak-hak hukum narapidana wanita. Untuk memenuhi aspek keterampilan ini tidak dapat dipungkiri peran akal sangatlah penting, tanpa terjaganya akal maka mustahillah aspek

\footnotetext{
${ }^{18}$ M. Quraish Sihab, Tafsir AL-Misbāh Pesan, Kesan dan Keserasian Al-Qur'an, Vol 3,h.232.

${ }^{19}$ Republik Indonesia , Keputusan Menteri Kehakiman Republik Indonesia No. M. 02-PK.04.10 Tahun 1990, Bab VII angka 2.
} 
keterampilan ini dapat dipenuhi, di dalam Islam, akal adalah karunia khusus yang diberikan Allah swt,. hanya kepada manusia, karena itu kita dianjurkan di dalam Islam untuk senantiasa menjaga akal agar dapat menciptakan kehidupan yang lebih baik.

Menjaga akal (hifz al-'aql) juga ditegaskan melalui tujuan disyariatkannya hukum (maqūsid al-Syari'ah). Jika hal ini tidak diindahkan maka hilanglah eksistensi akal sebagai alat untuk berfikir yang menjadi bagaian darūriyyat. Sementara dalam tataran hōjiyyat, mausia dianjurkan untuk memeperluas wawasan dan menambah ilmu penegatahuan.Untuk tahsiniyyat, dianjurkan agar tuidak menggunakan akal dalam menghayal negatife dan sebagainya. ${ }^{20}$

Segala usaha dalam menjaga akal merupakan suatu perbuatan yang mendapat ganjaran pahala, salah satu bentuk menjaga akal adalah dengan menuntut ilmu pengetahuan, dalam hal menuntut ilmu pengetahuan Rosulullah saw,. Pernah bersabda

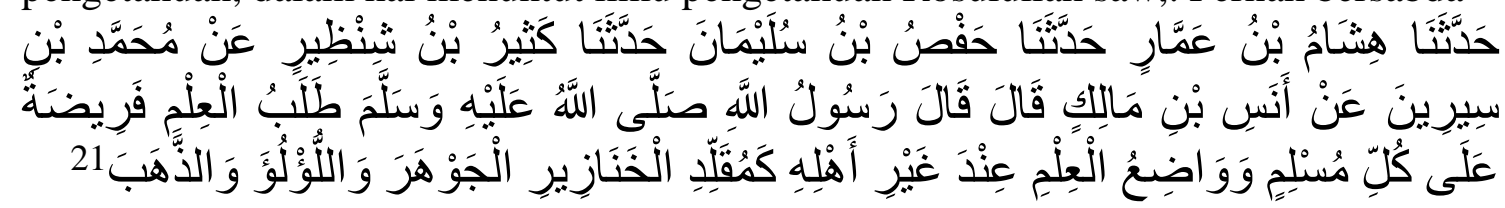

Artinya:

Telah menceritakan kepada kami Hisyam bin Ammar berkata, telah menceritakan kepada kami Hafsh bin Sulaiman berkata, telah menceritakan kepada kami Katsir bin Syinzhir dari Muhammad bin Sirin dari Anas bin Malik ia berkata; Rasulullah shallallahu 'alaihi wasallam bersabda: "Menuntut ilmu adalah kewajiban bagi setiap muslim. Dan orang yang meletakkan ilmu bukan pada pada ahlinya, seperti seorang yang mengalungkan mutiara, intan dan emas ke leher babi". (HR. Ibnu Majah No. 220)

Perbuatan yang kemudian dapat merusak akal dikategorikan sebagai suatu tindakan buruk yang merupakan hal yang dilarang oleh agama hal tersebut terdapat dalam Q.S al Maidah/5:90 dalam ayat tersebut sangat jelas larangan mengkonsumsi kahamr $^{22}$ (minuman keras). Dalam sunnah Rosulullah saw., juga dijelaskan tenatng sanksi bagi mereka yang mengkonsumsi khamar dengan didera sebanyak 40 kali. Dalam al Qur'an juga terdapat ayat yang menjelaskan betapa pentingnya menjaga akal, hal tersebut terdapat dalam Q.S al-Alaq/96:4-5:

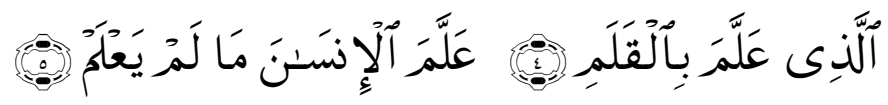

Terjemahnya:

\footnotetext{
${ }^{20}$ Muammar Bakry, Fiqih Prioritas: Konstruksi Metodelogi Hukum Islam dan Kompilasi Kaidah Prioritas Hukum Islam, h. 86.

${ }^{21}$ Muhammad bin Yazīd Abū'Abdillah al-Qazwainī, Sunan ibnu Mãjah (Bairūt: Dār al-Fikr, [t.th]), h. 462.

${ }^{22}$ Khamar dari segi bahasa adalah menutupi, sedangkan dari segi istilah adalah sari biji-bijian atau buah-buahan yang difermentasikan dan dapat memabukkan. Khamar dalam Islam merupakan induk dari segala bentuk kejahatan karena dapat menghilangkan akal sehat. Lihat: Abdi Wijaja, Penerapan Hukum Pidana Islam Menurut Mazhab Empat (Telaaah Konsep Hudud) ([t.t]: Alauddin University Prees, [t.th]), h. 164.
} 
"yang mengajar (manusia) dengan perantaran kalam, Dia mengajar kepada manusia apa yang tidak diketahuinya." 23

Setelah pada ayat pertama beliau menyuruh membaca dengan nama Allah yang menciptakan manusia dari segumpal darah, diteruskan lagi menyuruh membaca diatas nama tuhan. Sedang nama tuhan yang selalu akan diambil jadi sandaran hidup itu ialah Allah yang maha mulia, maha dermawan, maha kasih dan saying kepada mahluknya. "Dia yang mengajarkan dengan kalam". Itulah istimewanya tuhan itu lagi. Itulah kemulianya yang tertinggi. Yaitu diajarkanya kepada manusia berbagai ilmu, dibukanya berbagai rahasia, diserahkanya berbagai kunci untuk pembuka perbendaharaan Allah yaitu dengan qalam. Dengan pena disamping lidah untuk membaca, tuhanpun mentaksirkan pula bahwa dengan pena ilmu dapat dicatat. Pena itu kaku dan beku serta tidak hidup namun yang dituliskan oleh pena itu adalah berbagai hal yang dapat difahami oleh manusia "Mengajari manusia apa-apa yang dia tidak tahu". Terlebih dahulu Allah ta'ala mengajar manusia mempergunakan qalam. Sesudah dia pandai mempergunakan qalam itu banyaklah ilmu pengetahuan diberikan oleh allah kepadanya, sehingga dapat pula dicatat ilmu yang baru didapatnya itu dengan qalam yang sudah ada dalam tanganya. ${ }^{24}$

Ayat tersebut juga menjelaskan perintah Allah swt., kepada manusia untuk menuntut ilmu, dan dijelaskan pula sarana yang digunakan untuk menuntut ilmu yaitu kalam. Mencari ilmu adalah sebuah kewajiban bagi umat manusia dan mengamalkannya juga merupakan ibadah. Semakin tinggi ilmu yang dikuasai, semakin takut pula kepada Allah swt., sehingga dengan sendirinya akan mendekatkan diri kepada allah swt. ${ }^{25}$

d) Aspek Spritual Narapidana Wanita di Lembaga Pemasyarakatan Kelas IIA Watampone

Pembinaan spiritual yang dimaksudkan adalah bimbingan keagamaan dan hak untuk beribadah sesuai dengan kepercayaan masing-masing.Hak untuk beribadah sesuai dengan agama dan kepercayaan masing-masing termaktub di dalam pancasila pada sila pertama yang berbunyi "Ketuhanan Yang Maha Esa" kemudian terdapat pula dalam Pasal 14 Ayat 1 Huruf (a) UU.No. 12 Tahun 1995 Tentang Pemasyarakatan. Selanjutnya diatur dengan jelas mengenai syarat dan tatacara pelaksanaannya dalam Pasal 2 samapi dengan Pasal 4 Peraturan Pemerintah Republik Indonesia (PP RI) No 32 tahun 1999 Tentang Syarat dan Tata Cara Pelaksanaan Hak Warga Binaan Pemasyarakatan.

\section{Pasal 2}

(1) Setiap Narapidana dan Anak Didik Pemasyarakatan berhak untuk melakukan ibadah sesuai dengan agama dan kepercayaannya.

(2) Ibadah sebagaimana dimaksud dalam ayat (1) dilaksanakan di dalam lapas atau di luar lapas sesuai dengan program pembinaan.

(3)Tata cara pelaksanaan sebagaimana dimaksud dalam ayat (2) diatur lebih lanjut dengan Keputusan Menteri. ${ }^{26}$

\section{Pasal 3}

\footnotetext{
${ }^{23}$ Kementrian Agama RI, Al-Qur'an dan Terjemahanya, h. 905.

${ }^{24}$ Hamka, Tafsir Al-Azhar, Jilid10 (Jakarta: Pustaka Panjimas, 1998) h. 8059.

${ }^{25}$ Hamka, Tafsir Al-Azhar, h. 8060.

${ }^{26}$ Republik Indonesia, Peraturan Pemerintah Republik Indonesia No 32 tahun 1999 Tentang Syarat dan Tata Cara Pelaksanaan Hak Warga Binaan Pemasyarakatan, Pasal 2.
} 
(1) Pada setiap lapas wajib disediakan petugas untuk memberikan pendidikan dan bimbingan keagamaan.

(2) Jumlah Petugas sebagaimana dimaksud dalam ayat (1), disesuaikan dengan keperluan tiap-tiap lapas berdasarkan pertimbangan Kepala Lapas.

(3) Dalam melaksanakan pendidikan dan bimbingan keagamaan sebagaimana dimaksud dalam ayat (1), Kepala Lapas setempat dapat mengadakan kerja sama dengan instansi terkait, badan kemasyarakatan, atau perorangan. ${ }^{27}$

\section{Pasal 4}

Setiap Narapidana dan Anak Didik Pemasyarakatan wajib mengikuti program pendidikan dan bimbingan agama sesuai dengan agama dan kepercayaannya. ${ }^{28}$

Pembinaan pada aspek spritual merupakan suatu upaya untuk menjadikan narapidana lebih bertakwa kepada Tuhan Yang Maha Esa.Aspek spiritual ini telah memenuhi point perlindungan agama (hifzh al-dīn),) dalam teori maqūṣid alSyari'ah.Memelihara agama dalam peringkat darüriyyat yaitu meyakini bahwa Tuhan sebagai satu-satunya zat yang patut disembah, serta memepercai hal-hal gaib sebagaimana yang tersirat dalam simpul-simpul keimanan (arkân al Imâm). Memelihara agama dalam konteks hōjiyyatadalah melaksanakan kewajiban keagamaan yang masuk dalam peringkat primer, seperti melaksanakan ibadah shalat lima waktu dan sebagainnya jika sahalat dalam rukun-rukun Islam di abaikan, akan terancam eksistensi Islamdalam diri dan kehidupan manusia. Pada peringkat tahsiniyyat, yaitu mengikuti petunjuk agama guna menjungjung tinggi martabat manusia, sekaligus melengkapi kewajiban sebagai pengabdian kepada Tuhan seperti melakukan amalan-amalan yang bersifat tamabahan yang bernilai sunnahdalam berbagaiamalan seperti shalat sunnah, haji, sedekah, dan lain-lain. ${ }^{29}$

Islam melarang manusia untuk berbuat sesuatu yang dapat menghilangkan agama karena agama merupakan bagaian yang terpenting bagi manusia, tanpa agama manusia tidak memiliki acuan untuk menjalankan kehidupan di dunia dan akhirat kelak. Karena itulah Islam sangat mengharamkan yang namanya murtad $^{30}$ sebagaimanadalam Q.S al Baqarah/2:217:

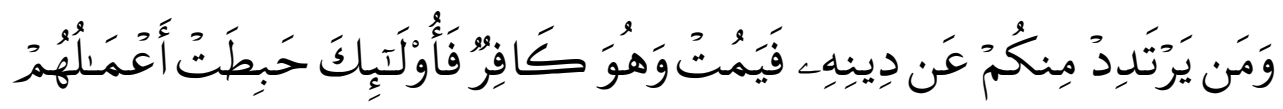

Terjemahnya:

Siapa saja yang murtad di antara kamu dari agamanya, lalu Dia mati dalam kekafiran, Maka mereka Itulah yang sia-sia amalannya..."31

${ }^{27}$ Republik Indonesia, Peraturan Pemerintah Republik Indonesia No 32 tahun 1999 Tentang Syarat dan Tata Cara Pelaksanaan Hak Warga Binaan Pemasyarakatan, Pasal 3.

${ }^{28}$ Republik Indonesia, Peraturan Pemerintah Republik Indonesia No 32 tahun 1999 Tentang Syarat dan Tata Cara Pelaksanaan Hak Warga Binaan Pemasyarakatan, Pasal 4.

${ }^{29}$ Muammar Bakry, Fiqih Prioritas: konstruksi Metodelogi Hukum Islam dan Kompilasi Kaidah Prioritas Hukum Islam, h. 84-85.

${ }^{30}$ Dalam Al-Qur'an pengertian tentang murtad tidak secara langsung dijelaskan, namun beberapa ayat dalam Al-Qur' an yang berkaitan dengan murtad antara lain surat An-Nissa: 137 dikatakan bahwa, sesungguhnya orang-orang yang beriman, kemudian kembali menjadi kafir bahkan bertambah ingkarnya, Allah tidaklah akan mengampuni mereka dan tidak akan menunjukinya jalan yang benar.

31 Jika kita ikuti Pendapat Ar Razy, Maka terjemah ayat di atas sebagai berikut: Katakanlah: "Berperang dalam bulan itu adalah dosa besar, dan (adalah berarti) menghalangi (manusia) dari jalan Allah, kafir kepada Allah dan (menghalangi manusia dari) Masjidilharam. tetapi mengusir penduduknya 
Imam Syafi'I menjelaskan bahwa orang yang terpercaya memeberitahu kami, dai Hamad bin Zaid, dari Yahya bin Zaid, dari Abu Umamah bin Sahl, dari Utsman bin Affan as., bahwa Rosulullah saw., bersabda,

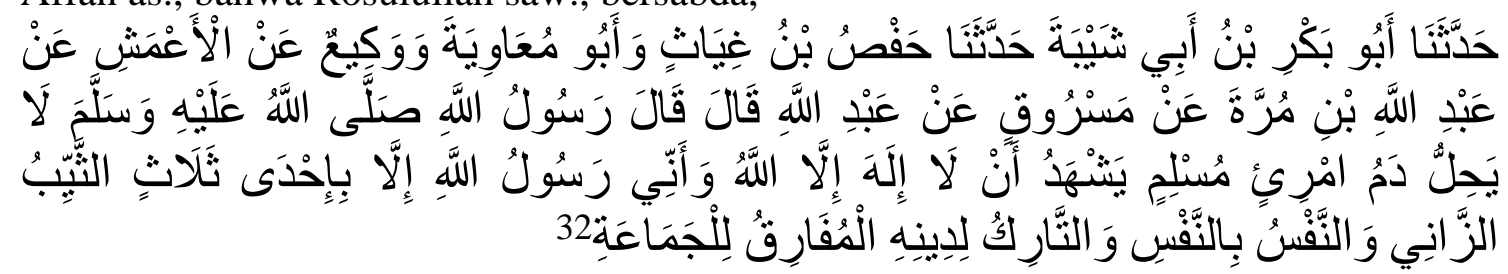

Artinya:

Telah menceritakan kepada kami Abu Bakar bin Abu Syaibah telah menceritakan kepada kami Hafsh bin Ghiyats dan Abu Mu'awiyah dan Waki' dari Al A'masy dari Abdullah bin Murrah dari Masruq dari Abdullah dia berkata, "Rasulullah shallallahu 'alaihi wasallam bersabda: "Tidak halal darah seorang muslim yang telah bersaksi bahwa tiada tuhan yang berhak untuk disembah selain Allah dan aku adalah utusan Allah, kecuali satu dari tiga orang berikut ini; seorang janda yang berzina, seseorang yang membunuh orang lain dan orang yang keluar dari agamanya, memisahkan diri dari Jama'ah (murtad)." (HR. Muslim No. 3175).

Imam Syafi'i melanjutkan, makna salah satu sabda Nabi Muhammad saw., tersebut adalah kekafiran setelah keimanan, tidak boleh diartikan selain ke kafiran yang menghalalkan darah, sebagai zinah setelah pernikahan, atau kata kekafiran kecuali setelah pelakunya bertaubat. Sebab , Al-Qur'an dan Sunnah Rosulullah saw., menunjukkan bahwa arti sabda Rosul saw., "kekafiran setelah keimanan" adalah apa bila dia tidak bertaubat dari ke kafiran. ${ }^{33}$

1. Kondisi Lembaga Pemasyarakatan Kelas IIA Watampone dalam Mewujudkan Perlindungan Hukum Hak-Hak Narapidana Wanita

Kondisi lapas kelas IIA Watampone yang dihuni oleh narapidana laki-laki dan wanita sangat memperihatinkan terkait hal tersebut bisa sangat berpengaruh akan proses berjalannya pelaksanaan pemenuhan hak-hak narapidana wanita di lapas kelas IIA Watampone. ${ }^{34}$ Pelaksanaan pemenuhan hak-hak narapidana sebagaimana terdapat dalam Pasal 14 Undang-Undang Nomor 12 Tahun 1995 di Lembaga Pemasyarakatan Kelas IIA Watampone, dijelaskan dalam 4 (empat) bagian, yakni sebagai berikut:

\section{a) Fasilitas yang Layak}

Fasilitas yang layak mencakup fasilitas dalam melakukan ibadah sesuai dengan agama/kepercayaannya, mendapat perawatan baik perawatan rohani maupun jasmani,

dari Masjidilharam (Mekah) lebih besar lagi (dosanya) di sisi Allah." Pendapat Ar Razy ini mungkin berdasarkan pertimbangan, bahwa mengusir Nabi dan sahabat-sahabatnya dari Masjidilharam sama dengan menumpas agama Islam. Sedangkan fitnah di sini berarti penganiayaan dan segala perbuatan yang dimaksudkan untuk menindas Islam dan muslimin. Lihat Kementrian Agama RI, Al-Qur'an dan Terjemahanya, h. 42.

${ }^{32}$ Muslim bin al-Hajjāj Abu al-Husain al-Qusyairiāl-Naisābūri, Șahih Muslim (Bairūt: Dār Ihyā al-Turāś al-'Arabī, [t.th]), h. 366.

${ }^{33}$ Syaikh Ahmad Musthafa al-Farran, Tafsir Imam Syafi'I Menyelamikedalaman kandungan AlQur'an terjh, Ali Sultan dan Fedrian Hasmad, Jilid. 1 (Jakarata: Almahira, 2006), h. 351.

${ }^{34}$ Azhar (34 tahun), Ka. Subsi, Registrasi, wawaancara oleh penulis di Lembaga Pemasyarakatan Kelas IIA Watampone, 21 Maret 2018. 
mendapatkan pendidikan/pengajaran, mendapatkan pelayanan kesehatan/makanan yang layak, menyampaikan keluhan dan mendapatkan bahan bacaan/mengikuti siaran media massa lainnya yang tidak dilarang, serta fasilitas dalam menerima kunjungan keluarga, penasihat hukum, atau orang tertentu lainnya.

Pertama, fasilitas dalam melakukan ibadah sesuai dengan agama/kepercayaannya.Fasilitas yang disediakan oleh pihak lapas kelas IIA Watampone dalam rangka pemenuhan hak beribadah, bagi yang beragaman Islam yaitu disediakannya tempat beribadah berupa satu buah masjid. Waktu penggunaan tempat ibadah dibatasi karena lokasi tempat masjid yang berada di luar blokkhusus narapidana wanita. Misalnya untuk sholat lima waktu lebih banyak dilakukan di dalam kamar, terkait dengan waktu buka blok yang hanya pagi hari dari pukul 07:30-16:00 Wita. ${ }^{35}$

Kedua, fasilitas dalam mendapatkan perawatan rohani dan jasmani.Setiap narapidana wanita yang terdapat di lapas kelas IIA Watampone berhak mendapatkan perawatan rohani dan jasmani.Lapas kelas IIA Watampone dalam pelaksanaannya belum menyediakan fasilitas khusus dalam melakukan bimbingan kerohanian dan budi pekerti.Oleh sebab itu, bimbingan kerohanian dan budi pekerti dilakukan di masjid, namun hal tersebut belum maksimal karena antara narapidana pria dan narapidana wanita bercampur dalam satu majelis. ${ }^{36}$

Perawatan jasmani yang mencakup penyediaan peralatan mandi dankesempatan berolahraga.Peralatan mandi tersebut, hanya didapatkan satu kali oleh narapidana, yaitu pada saat setelah didaftar dan untuk selanjutnya narapidana mengusahakan sendiri. ${ }^{37}$ Idealnya, mengenai perlengkapan mandi tersebut merupakan hak yang harus dipenuhi oleh pihak lapas kepada narapidana secara cuma-cuma.Pihak lapas dalam menyediakan fasilitas kamar mandi dapat dikatakan belum memadahi, karena tembok pembatas kamar mandi dengan rungan hanya setinggi 1 meter, sehingga apabila ruagan yang dihuni lebih dari satu orang dapat menimbulkan ketidak nyamanan. Namun kondisi tersebut sudah menjadi aturan baku yang ditetapkan oleh pemerintah. ${ }^{38}$ Kegiatan olahraga berupa bola volley, sepaktakrow, bulutangkis, tenis meja dan senam pagi. Ketersediaan sarana rekreasi di bidang kesenian berupa latihan musik band, dan satu set alat musik band berupa 1 buah gitar listrik, 1 buah gitar bass, satu set drum, 1 buah keyboard, dan 2 buah mic.

Untuk kegiatan olahraga dilaksanakan setiap hari jumat pagi mulai 07:30 sampai 09:00 WITA sedangkan untuk kegiatan kesenian dilaksanakan setiap hari jumat setelah kegiatan olahraga selesai dan dilanjutkan jumat sore setelah sholat ashar.Namun untuk narapidana wanita penggunaan fasilitas tersebut tidak dapat dilakukan selain minat dari narapidana wanita yang minim pemanfaatan fasilitas tersebut di dominasi oleh narapidana pria. ${ }^{39}$

\footnotetext{
${ }^{35}$ Surianto (37 tahun), Ka. Subsi. Bimbingan Kemasyarakatan dan Perawatan, wawaancara oleh penulis di Lembaga Pemasyarakatan Kelas IIA Watampone, 25 Maret 2018.

${ }^{36} \mathrm{Abu}$ (49 tahun), Kasi Pembinaan dan Pendidikan, wawaancara oleh penulis di Lembaga Pemasyarakatan Kelas IIA Watampone, 28 Maret 2018.

${ }^{37} \mathrm{Abu}$ (49 tahun), Kasi.Pembinaan dan Pendidikan, wawaancara oleh penulis di Lembaga Pemasyarakatan Kelas IIA Watampone, 28 Maret 2018.

${ }^{38}$ Azhar (34 tahun), Ka. Subsi.Registrasi, wawaancara oleh penulis di Lembaga Pemasyarakatan Kelas IIA Watampone, 21 Maret 2018.

${ }^{39}$ Surianto (37 tahun), Ka. Subsi. Bimbingan Kemasyarakatan dan Perawatan, wawancara oleh penulis di Lembaga Pemasyarakatan Kelas IIA Watampone, 25 Maret 2018.
} 
Ketiga, fasilitas dalam mendapatkan pendidikan dan pengajaran.Lapas kelas IIA Watampone terdapat program kejar paket A, B dan C yang dilaksanakan setiap hari kerja dengan mendatangkan guru dari Pusat Kegiatan Belajar Masyarakat (PKBM) Armila Kabupaten Bone. Petugas menyeleksi narapidana yang wajib mengikuti dan melihat latar belakang pendidikan narapidana tersebut. Kegiatan lain yang berkaitan dengan pendidikan dan pengajaran adalah pemberian pelatihan keterampilan sebagai bekal yang dapat dikembangkan setelah narapidana tersebut bebas. Pelatihan keterampilan tersebut meliputi: pembuatan bingkai foto, bosara, tempat tisu, kipas tangan dan menjahit bagi narapidana perempuan serta latihan perbengkelan, menjahit, peternakan, perkebunan dan pertukangan bagi narapidana laki- laki. ${ }^{40}$

Keempat, fasilitas kesehatan dan makanan yang layak. Fasilitas kesehatan yang terdapat di lapas kelas IIA Watampone berupa sebuah klinik dan tenaga medis yang terdiri dari 1 orang dokter umum dan 3 orang perawat yang bertugas untuk memberikan resep obat-obatan dan memeriksa kondisi kesehatan narapidana. ${ }^{41}$ Pemberian pelayanan kesehatan bagi narapidana di lapaskelas IIA Watampone dilakukan degan cara melakukan pemeriksaan kesehatan rutin yang dilakukan satu kali satu minggu dan pemberian resep obat-obatan yang dibutuhkan bagi narapida yang sakit. ${ }^{42}$ Pemberian pelayanan kesehatan bagi narapidana di lapaskelas IIA Watampone dilakukan degan cara melakukan pemeriksaan kesehatan rutin yang dilakukan satu kali satu minggu dan pemberian resep obat-obatan yang dibutuhkan bagi narapida yang sakit. ${ }^{43}$

Fasilitas kesehatan dalam memenuhi kebutuhan makanan narapidana dalam sehari hanya tersedia anggaran sebesar Rp15.000. (lima belas ribuh rupiah) pernarapidana, dalam sehari narapidana makan sebanyak 3 kali jadi anggaran tersebut menjadi Rp.5.000. (lima ribu rupiah) persatu kali makan, apabila jumlah ini di bandingkan dengan haraga makanan diwarung makan tetu saja kita akan mendapatkan harga Rp. 15.000. (lima belas ribuh rupiah) perporsi untuk satu kali makan. Jika melihat kondisi ini tentu saja untuk memenuhi kecukupan gizi narapidana wanita tentu saja tidak terlaksana dengan baik, terlebih lagi bagi narapidana wanita yang membutuhkan tambahan gizi seperti narapidana wanita yang sedang hamil atau menyusui. ${ }^{44}$

Kelima, Menyampaikan keluhan.Menyampaikan keluhan merupakan hak bagi seluruh narapidana termasuk narapidana wanita di lapas kleas IIA Watampone yang dilanggar hak-hak asasinya oleh petugas lapas maupun sesama narapidana wanita. Pihak lapas kelas IIA Watampone telah menyediakan pegawai bagian penerima keluhan narapidana yang mempunyai keluhan masalah, dengan cara narapidana melapor kepada

${ }^{40}$ Surianto (37 tahun), Ka. Subsi. Bimbingan Kemasyarakatan dan Perawatan, wawaancara oleh penulis di Lembaga Pemasyarakatan Kelas IIA Watampone, 25 Maret 2018.

${ }^{41}$ Muniarti (38 tahun), Perawat, wawaancara oleh penulis di Lembaga Pemasyarakatan Kelas IIA Watampone, 28Maret 2018.

${ }^{42}$ Muniarti (38 tahun), Perawat, wawaancara oleh penulis di Lembaga Pemasyarakatan Kelas IIA Watampone, 28Maret 2018.

${ }^{43}$ Muniarti (38 tahun), Perawat, wawaancara oleh penulis di Lembaga Pemasyarakatan Kelas IIA Watampone, 28Maret 2018.

${ }^{44}$ Lukman Amin (59 tahun), Ka.Lapas, wawancara oleh penulis di Lemabaga Pemasyarakatan Kelas IIA Watampone, 28 Maret 2018. 
petugas blok masing-masing, kemudian petugas blok menyampaikan kepada pegawai bagian yang pengeluhan. ${ }^{45}$

Keenam, fasilitas dalam mendapatkan bahan bacaan dan mengikuti siaran media massa lainnya yang tidak dilarang.Lapaskelas IIA Watampone juga mneyediakan perpustakaan, narapidana diberikan kesempatan untuk mengunjungi dan meminjam buku yang ada di perpustakaan, meskipun masih sangat sederhana dan terbatas pada buku yang didapatkan atau diterima dari Direktorat Jenderal Pemasyarakatan. ${ }^{46}$ Bagi narapidana wanita kesempatan untuk memebaca diperpustakaan sangatlah minim, hal ini disebabkan letak perpustakaan yang beradah di antara blok-blok narapidana pria, selain itu dalam perpustakaan tersebut sering dijumpai narapidana pria yang bertelanjang dada dikarenakan kondisi perpustakaan yang tidak dilengkapi penyejuk ruagan. ${ }^{47}$

Selain tersediannya bahan bacaan di perpustakaan yang telah di sediakan pihak lapas, narapidana juga dapat membaca surat kabar atau majalah yang dibawa atau dikirim oleh keluarga. Selain itu narapidaa juga diperbolehkan melihat dan mendengar media elektronik, seperti radio dan televisi yangterdapat di depan kamar masingmasing. Mereka dapat menikmati hal tersebut pada saat siang hari atau pada saat mereka sedang tidak ada kegiatan. ${ }^{48}$ Untuk menikmati fasilitas siaran televisi narapidana wanita di lapas kelas IIA Watampone mengaku tidak nyaman karena satu buah televisi harus dinikmati oleh 20 (dua puluh) orang penghuni blok wanita. ${ }^{49}$

Ketujuh, fasilitas dalam menerima kunjungan keluarga, penasihat hukum, atau orang tertentu lainnya.Narapidana diberikan kesempatan untuk mendapatkan kunjungan baik keluarga, teman, maupun penasihat hukumnya. Kunjungan bagi narapidana dicatat dalam buku daftar kunjungan dan sediakan ruangan khusus untuk menerima kunjungan bagi narapidana. ${ }^{50}$

Petugas yang bertugas di tempat kunjungan mempunyai kewajiban yang harus dilaksanakan. Kewajiaban petugas tersebut anatara lain: ${ }^{51}$

1) Memeriksa dan meneliti keterangan identitas diri pengunjung;

2) Menggeledah pengunjung dan memeriksa barang bawaannya.

Jadwal kunjungan bagi narapidana yaitu pada hari selasa, kamis dan sabtu pada pukul 09.00 sampai 12.00 Wita dan dilanjutkan pada pukul 13.30 sampai 15:00 Wita. ${ }^{52}$ b) Keamanan Khusus

\footnotetext{
${ }^{45}$ Surianto (37 tahun), Ka.Subsi.Bimbingan Kemasyarakatan dan Perawatan, wawaancara oleh penulis di Lembaga Pemasyarakat an Kelas IIA Watampone, 28Maret 2018.

${ }^{46}$ Surianto (37 tahun), Kasi Bimbingan Kemasyarakatan dan Perawatan, wawaancara oleh penulis di Lembaga Pemasyarakatan Kelas IIA Watampone, 28Maret 2018.

${ }^{47}$ Irmah Safitrianhy (21 tahun), Napi, wawancara penulis di Lemabaga Pemasyarakatan Kelas IIA Watampone, 23 Maret 2018.

${ }^{48}$ Surianto (37 tahun), Ka.Subsi.Bimbingan Kemasyarakatan dan Perawatan, wawaancara oleh penulis di Lembaga Pemasyarakatan Kelas IIA Wat ampone, 28Maret 2018.

${ }^{49}$ Irmah Safitrianhy (21 Tahun), Napi, wawancara penulis di Lemabaga Pemasyarakatan Kelas IIA Watampone, 23 Maret 2018.

${ }^{50}$ Surianto (37 tahun), Ka.Subsi.Bimbingan Kemasyarakatan dan Perawatan, wawaancara oleh penulis di Lembaga Pemasyarakatan Kelas IIA Watampone, 28Maret 2018.

${ }^{51}$ Azhar (34 tahu), Ka. Subsi.Registrasi, wawancara oleh penulis di Lembaga Pemasyarakatan Kelas IIA Watampone, 21 Maret 2018.

${ }^{52}$ Azhar (34 tahu), Ka.Subsi. Registrasi, wawancara oleh penulis di Lembaga Pemasyarakatan Kelas IIA Watampone, 21 Maret 2018.
} 
Pelaksanaan pengamanan dilakukan oleh satuan pengamanan, yakni unit yang melakukan tugas melakukan pencegahan, penindakan, penanggulangan dan pemulihan gangguan keamanan dan ketertiban di lapas dan rutan. ${ }^{53}$ Selain itu, pada Pasal 5 Permenkumham 33 Tahun 2015 Tentang Pengamanan Pada Lapas dan Rutan, disebutkan bahwa dalam menyelenggarakan pengamanan terhadap narapidana dan tahanan wanita dilakukan dengan mengutamakan keberadaan petugas wanita. ${ }^{54}$

Narapidana wanita dalam menjalani masa pidannya tentu saja membutuhkan pengamanan khusus seperti tersediannya tenaga staf keamanan wanita dan adanya blok khusus wanita. ${ }^{55}$ Kondisi lapas yang juga dihuni oleh narapidana pria sangat memebatasi aktifitas narapidana wanita karena hampir seluruh aktifitas narapidana wanita dilakukan di dalam blok khusus wanita, terlebih lagi untuk kegiatan-kegiatan yang dilaksanakan diluar blok seperti saat ada kegiatan kerjasama oleh pihak lapas degan pihak SKPD (Satuan kerja perangkat daerah), Ormas (organisasi Masyarakat), LSM (Lembaga Sosial Masyarakat) atau perusahaan narapidana wanita jarang ikut serta dikarenakan pada kegiatan tersebut didominasi oleh narapidana pria. ${ }^{56}$

Narapidana wanita yang keluar untuk membeli keperluan pribadi di koperasi tidak pernah mendapatkan pengawalan khusus dari staf keamanan wanita maupun pria. ${ }^{57}$ Begitu juga dengan minimnya pengawalan saat melakukan kegiatan senam dipagi hari yang dilakukan bersamaan dengan narapidana pria.Untuk meminimalisir potensi terjadinya hal-hal yang tidak diingginkan pemerintah telah meregulasikan pembentukan lapas khusus wanita hal ini diterdapat dalam pasal 12 ayat 2 UU No. 12 Tahun 1995 tentang Pemasyarakatan.Namun pada kenyataannya pada lapas kelas IIA Watampone hanya terdapat blok khusus wanita.

Menurut pendapat salah satu narapidana wanita di lapas kelas IIA Watampone keamanan belok sudah cukup baik. ${ }^{58}$ Pendapat narapidana tersebut tentang kondisi keamanan lapas didasari dari minimnya pengetahuan narapidana atas apa saja yang menjadi hak-hak mereka sebagai narapidana, salah satunya hak untuk mendapatkan rasa aman. Hal ini terjadi dikarenakan minimnya sosialisasi pihak lapas terhadap narapidana mengenai hak dan kewajiban mereka sebagai narapidana.

Keadaan di atas telah memberikan gambaran bahwa dengan adanya blok khusus bagi narapidana wanita belum mampu menciptakan keamanan dan ketentraman bagi narapidana wanita di lapas kelas IIA Watampone. Kondisi minimnya jumlah staf pengamanan dengan perbandingan antara staf pengamanan lapas dengan narapidana wanita dalam satu hari adalah satu staf pengamanan berbanding sepuluh dengan

\footnotetext{
${ }^{53}$ Republik Indonesia,Permenkumham 33 Tahun 2015 Tentang Pengamanan Pada Lapas dan Rutan, Pasal 1 ayat (7).

${ }^{54}$ Republik Indonesia, Permenkumham 33 Tahun 2015 Tentang Pengamanan Pada Lapas dan Rutan, Pasal 5.

${ }^{55}$ M. Arfandi (48 tahun), Ka KPLP, wawancara oleh penulis di Lembaga Pemasyarakatan Kelas IIA Watampone, 25 Maret 2018.

${ }^{56}$ Nurmala (48 tahun), Narapidana, wawancara oleh penulis di Lembaga Pemasyarakatan Kelas IIA Watampone, 25 Maret 2018.

${ }^{57}$ Nurmala (48 tahun), Narapidana, wawancara oleh penulis di Lembaga Pemasyarakatan Kelas IIA Watampone, 25 Maret 2018.

${ }^{58}$ Nurmala (48 tahun), Narapidana, wawancara oleh penulis di Lembaga Pemasyarakatan Kelas IIA Watampone, 25 Maret 2018.
} 
narapidana wanita, yang tentu dengan keadaan demikian, pengamanan terhadap narapidana wanita di lapas kelas IIA Watampone masih kurang maksimal.

\section{c) Pelayanan Khusus Bagi Narapidana Wanita}

Tersedianya pelayanan khusus di lapas kelas IIA Watampone dapat dilihat dari dari tiga aspek yaitu ketersediaan tenaga pengamanan wanita untuk memberikan pelayanan keamanan bagi napi wanita, tenaga ahli wanita untuk pembinaan narapidana wanita baik dibidang pembinaan kemandirian, kesenian, maupun pembinaan di bidang spritual, dan tenaga medis wanita untuk memberikan pelayanan kesehatan bagi narapidan wanita. ${ }^{59}$ Ketiga aspek tersebut akan dijelaskan lebih jelas sebagai berikut:

Pertama, pelayanan dalam bidang keamanan.Blok khusus wanita terdapat staf keamanan wanita berjumlah 8 (delapan) orang, yang akan mengawasi 16 (enambelas) orang narapidana wanita dan 3 (tiga) orang tahanan. ${ }^{60}$ Staf keamanan tersebut bekerja secara bergantian, sehingga dalam menjalankan tugasanya, 2 (dua) orang stafkeamanan mengawasi 16 (enam belas) orang narapidana wanita dan 3 (tiga) orang tahanan, sedangkan idelnya 1 (satu) orang staf keamanan mengawasi 3 (tiga) orang narapidana wanita. ${ }^{61}$ Namun tidak jarang di dalam blok khusus wanita hanya terdapat satu staf pengaman yang bertugas menajaga kondisi keamanan blok yang berisikan 16 (enambelas) orang narapidana wanita dan 3 (tiga) orang tahanan, ${ }^{62}$ disamping itu staf keamanan juga tidak dibekali senjata pengaman, seperti serbuk merica,senjata angi, pentungan atau borgol pengaman. Menurut penulis pengadaaan senjata penagaman tentu saja dibutuhkan untuk berjaga-jaga dan menhindari hal-hal yang tidak diinginkan terlebih lagi di lapas kelas IIA Watampone hanya terdapat blok khusus wanita dimana pada bagain luar blok terdapat ratusan narapidana pria yang beraktifitas.

Minimnya staf kemaman wanita memang menjadi satu masalah serius yang sudah lama dan belum dapat diatas.Kondisi ini juga dipertegas oleh M. Arfandi selaku Ka KPLP yang bertanggung jawab atas keamanan seluruh narapidana yang ada di lapas kelas IIA Watampone termasuk narapidana wanita.Minimnya tenaga keamanan wanita tentu saja menjadi gamabaran tidak maksimalnya pelayanan khusus narapidana wanita pada aspek keamanan. ${ }^{63}$

Kedua, pelayanan khusus pada bidang pembinaan narapidana wanita.Kehadiran pembina wanita di bidang pembinaan kemandirian bagi narapidana wanita di lapas kelas IIA Watampone telah terpenuhi, hanya saja belum berjalan dengan maksimal.Hal ini dapat dilihat dari minimnya bentuk-bentuk pelatihan kemandirian yang diberikan. ${ }^{64}$ Selain minimnya bentuk pelatihan kemandirian yang diberikan kehadiran pembina tersebut di lapas kelas IIA Watampone juga tergolong minim karena pembina

\footnotetext{
${ }^{59} \mathrm{Abu}$ (49 tahun), Ka. Binadin, wawancara oleh penulis di Lembaga Pemasyarakatan KelasIIA Watampone, 29 Maret 2018.

${ }^{60}$ Nurmala (48 tahun), Narapidana, wawancara oleh penulis di Lembaga Pemasyarakatan Kelas IIA Watampone, 25 Maret 2018.

${ }^{61}$ M. Arfandi (48 tahun), Ka KPLP, wawancara oleh penulis di Lembaga Pemasyarakatan Kelas IIA Watampone, 25 Maret 2018.

${ }^{62}$ Nurmala (48 tahun), Narapidana, wawancara oleh penulis di Lembaga Pemasyarakatan Kelas IIA Watampone, 25 Maret 2018.

${ }^{63} \mathrm{M}$. Arfandi (48 tahun), Ka KPLP, wawaancara oleh penulis di Lembaga Pemasyarakatan Kelas IIA Watampone, 25 Maret 2018.

${ }^{64} \mathrm{Abu}$ (49 tahun), Kasi. Binadin, wawaancara oleh penulis di Lembaga Pemasyarakatan Kelas IIA Watampone, 28Maret 2018.
} 
hanya hadir satu kali seminggu, sedangkan narapidana wanita mengaku kehadiran pembina saat melakukan kegiatan kemandirian sangat membantu. ${ }^{65}$

Pembinaan dibidang kesenian bagai narapidana wanita di lapas kelas IIA Watampone belum pernah terlaksana hal ini disebabkan tidak adanya pembina dan tidak terdapat sarana untuk melakukan kegaiatan tersebut di dalam blok khusus. Sarana untuk pengemabangan bakat di bidang kesenian hanya terdapat di aula serbaguna lapas kelas IIA Watampone dimana keberadaan aula yang berda ditegah-tegah lapas dan dominasi narapidana pria yang menggunakan sarana tersebut menjadi kendala, selain itu diperparah dengan jadwal pembinaan di bidang kesenian yang hanya dilaksanakan satu kali satu minggu yaitu hanya pada hari jum'at. ${ }^{66}$

Ketiga, pelayanan khusus dalam bidang kesehatan.Untuk pelayanan khusus dibidang kesehatan dibagi menjadi dua bagian yaitu kesehatan jasmani dan kehatan rohani.Pada bidang kesehatan jasmani kehadiran tenaga medis wanita dan dokter wanita di lapas kelas IIA Watampone adalah hal yang cukup baik bagi narapidana wanita, karena degan hadirnya tenaga medis yang seluruhnya adalah wanita memebuat narapidana wanita di lapas kelas IIA Watmpone menjadi tidak segan melakukan konsultasi kesehatan atau pun meminta pelayanan kesehatan. ${ }^{67}$

Pada bidang pelayanan kesahatan spiritual piahak lapas kelas IIA Watampone telah meneydiakan tenaga ahli wanita untuk memberikan pelayanan dibidang spiritual.Pelayanan kesehatan spiritual ini diisi dengan kegiatan-kegiatan keagamaan seperti, tausiyah, bimbingan bacatulis al-Qur'an, dan pembinaan yang menyangkut degan keperibadian narapidana wanita. ${ }^{68}$ Kehadiran pembina spiritual wanita di lapas kelas IIA Watampone telah terpenuhi dan proses pembinaanya berjalan cukup baik. Menurut salah satu narapidana wanita di lapas kelas IIA Watampone pembinaan spiritual ini sangat memberikan manfaat bagi narapidana wanita karena selain memicu kesadaran diri narapidana wanita atas kesalahan yang pernah dilakukan, pembinaan spiritual ini juga meningkatkan kualitas baca tulis al-Qur'an narapidana wanita. ${ }^{69}$

\section{d) Pembinaan Khusus Bagi Narapidana Wanita}

Bentuk pembinaan yang diberikan pihak lapas kelas IIA Watampone kepada narapidana haruslah disesuaikan dengan kodratnya sebagai seorang wanita, Menurut salah satu narapidana wanita bentuk pelatihan yang diberikan pihak lapas kepada narapidana wanita sejak awal menjalani masa pidananya sampai dengan sekarang bentuk pelatihan yang diberikan tidak ada perubahan. ${ }^{70}$ Ketersediaan alat dan bahan yang terbatas juga menjadi faktor pendukung minimnya bentuk kerajinan tangan yang

\footnotetext{
${ }^{65}$ ST. Madina (38 tahun), Narapidana, wawaancara oleh penulis di Lembaga Pemasyarakatan Kelas IIA Watampone, 21Maret 2018.

${ }^{66} \mathrm{ST}$. Madina (38 tahun), Narapidana, wawaancara oleh penulis di Lembaga Pemasyarakatan Kelas IIA Watampone, 21Maret 2018.

${ }^{67}$ Fauzitami Sari (22 tahun), Narapidana, wawaancara oleh penulis di Lembaga Pemasyarakatan Kelas IIA Watampone, 27Maret 2018.

${ }^{68} \mathrm{Abu}$ (49 tahun), Kasi.Binadin, wawaancara oleh penulis di Lembaga Pemasyarakatan Kelas IIA Watampone, 28Maret 2018.

${ }^{69}$ ST. Madina (38 tahun), Narapidana, wawaancara oleh penulis di Lembaga Pemasyarakatan Kelas IIA Watampone, 21Maret 2018.

${ }^{70}$ ST. Madina (38 tahun), Narapidana, wawaancara oleh penulis di Lembaga Pemasyarakatan Kelas IIA Watampone, 21Maret 2018.
} 
dapat dibuat, hal ini dikarenakan pihak lapas bergantung pada ketersediaan anggaran untuk pengadaan alat dan bahan. ${ }^{71}$

Pembinaan dibidang keterampilaan ini tidak berjalan secara maksimal.Hal tersebut dapat dilihat dari bentuk-bentuk pelatihan kerajianan yang diberikan sudah ketinggalan jaman dan tidak inovatif, adapun bentuk pelatihan menjahit yang diberikan adalah menjahit dan membuat kerajianan tangan.Minimnya betuk pelatihan juga menjadi kendala, padahal ada banyak bentuk-bentuk pelatihan yang bisa diberikan kepada narapidana wanita antara lain seperti, pelatiahan tatarias, tataboga, membatik/menenun kain dan pelatihan bahasa asing.

2. Kondisi Narapidana Wanita di Lembaga Pemasyarakatan Kelas IIA Watampone Dalam Mewujudkan Perlindungan Hukum Hak-Hak Narapidana Wanita

Kondisi narapidana wanita di lapas kelas IIA Watampone memiliki permasalahan yang cukup kompleks, hal ini dapat dilihat dari penjabaran sebelumnya seperti banyaknya kendala yang dihadapai seperti masalah fasilitas, pelayanan, pembinaan dan sebagainya.Menciptakan suasana kekeluargaan didalam lapas menjadi hal paling penting untuk dibangun agar dapat tercapai suasana yang kondusif dan nyaman. Penulis membagi kondisi narapidana wanita di lapas kelas IIA Watampone dibagi menjadi 3 (tiga) aspek yakni sebagai berikut:

\section{a) Integritas Sesama Narapidana Wanita}

Andres Harefa menjelaskan bahwa integritas dapat diartikan menjadi tiga tanda kunci yang dapat diamati yaitu menunjukkan kejujuran, memenuhi komitment, dan mengerjakan sesuatu dengan konsisten. ${ }^{72}$ Kondisi narapidana wanita di lapas kelas IIA Watampone sudah terbangun integritas sesama narapidana wanita.Salah satu indikator integritas yang ditunjukkan oleh narapidana wanita di lapas kelas IIA Watampone adalah adanya sikap jujur yang diaplikasikan dalam keseharianya.

Narapidana wanita di lapas kelas IIA Watampone dalam menjalankan aktifitas keseharian menunjukkan sikap kejujuran yang cenderung meningkat apabila dibandingkan saat pertama kali memasuki lembaga pemasyarakatan. Salah satu contoh konkret ditandai dengan sikap narapidana dalam kesehariannya yang meminta izin terlebih dahulu saat akan mengambil atau menggunakan barang milik narapidana wanita lainnya. Tetapi apabila barang tersebut terlanjur dipakai, maka narapidana wanita tersebut tetap memberitahukan kepada pemilik barang yang telah digunakannya. ${ }^{73}$

Ciri integritas lainnya, yang dilakukan oleh narapidana wanita di lapas adalah komitmen dalam mengerjakan sesuatu.Secara sederhna hal ini ditunjukkan dengan komitmen seluruh narapidana wanita dalam upaya pemebersihan blok. Tanpa adanya paksaan dari pihak petugas lapas, narapidana wanita di kelas IIA Watampone selalu ikut serta dalam upaya menjaga kebersihan blok khusus wanita. ${ }^{74}$

\footnotetext{
${ }^{71} \mathrm{Abu}$ (49tahun), Kasi. Binadin, wawaancara oleh penulis di Lembaga Pemasyarakatan Kelas IIA Watampone, 28Maret 2018.

${ }^{72}$ Amir Yamsuddin, Integritas Penegak Hukum (Hakim, Jaksa, Polisi, dan Pengacara) (Jakarta: Buku Kompas, 2008), h. 13

${ }^{73}$ Srianthy (32 tahun), Narapidana, wawancara oleh penulis di Lembaga Pemasyarakatan Kelas IIA Watampone, 21 Maret 2018.

${ }^{74}$ Rini Anggeriani (25 tahun), Staff KPLP, wawancara oleh penulis di Lembaga Pemasyarakatan Kelas IIA Watampone, 21 Maret 2018.
} 
Perilaku konsistensi ditunjukkan oleh narapidana wanita di lapas dapat dilihat dari konsistensi narapidana wanita dalam mematuhi peraturan yang ada di dalam lapas. Hal ini juga ditegaskan oleh salah satu staf pengamanan di blok khusus wanita, bahawa narapidana wanita di lapas kelas IIA Watampone tidak pernah melakukan pelanggaran yang berat. ${ }^{75}$

Sikap integritas yang ditunjukkan narapidana wanita di lapas kelas IIA Watampone merupakan bentuk keberhasilan lapas dalam melakukan pembinaan kepribadian hal ini tergambarakan secara jelas bagaimana narapidana wanita yang ada di lapas kelas IIA watampone memperlihatkan adanya kemajuan pada prilaku jujur, komitment dan konsisten.

\section{b) Perilaku Bermartabat Narapidana Wanita}

Bermartabat yang dimaksudkan dalam penulisan ini adalah keadaan narapidana wanita selama dalam lembaga pemasyarakatan melakukan seluruh aktivitas yang bermartabat selaku wanita.Secara nyata, sikap yang bermartabat dapat dilihat dari berbagai aspek diantaranya adalah cara berpakaian dan etika dalam berkomunikasi.

Mengenai cara berpakaian yang sopan sebagai bagaian dari perilaku yang bermartabat, narapidana wanita di lapas menunjukkan cara berpakaian yang sopan. Meskipun cara berpakaian narapidana wanita yang beragama Islam belum memenuhi standar pakaian yang ditentukan dalam syariat Islam. ${ }^{76}$ Narapidana wanita di lapas dalam berpakaian cenderung mengggunakan menggunakan pakaian yang ketat dan menampakkan lekuk tubuh.

Cara berkomunaksi sehari-hari yang dilakukan oleh narapidana wanita di lapas, masih terkesan tidak sopan dan tidak selayaknya diucapkan dalam etika berkomunikasi. ${ }^{77}$ Sebagaimana yang diuraikan oleh salah seorang staf pengamanan blok khusus narapidana wanita, bahwa kadangkala dalam menegur atau menyapa sesama narapidana wanita, terkadang menggunakan sapaan yang tidak sopan seperti "weehh/anu”, sapaan seperti ini sangat tidak sopan apa lagi jika diucapkan untuk menyapa atau menegur orang yang lebih dewasa. ${ }^{78}$

Di sisi lain, cara bertutur kata yang terkesan lebih sopan ditunjukkan oleh narapidana wanita ketika bertemu dengan petugas lapas. Hal yang sama juga ditunjukkan oleh narapidana wanita, saat penulis mengunjungi lapas kelas IIA Watampone. Seluruh narapidana wanita yang diwawancarai oleh penulis memperlihatkan sikap yang sopan dan tutur kata yang sopan. ${ }^{79}$

Keadaan di atas dapat disimpulkan bahwa tujuan lembaga pemasyarkatan kelas IIA Watampone untuk membentuk akhlak narapidana khususnya narapidana wanita agar bermartabat telah tercapai sekalipun belum secara maksimal.Untuk menciptakan perilaku bermartabat selain dibutuhkan pembinaan, hal yang juga sangat penting

${ }^{75}$ Rini Anggeriani (25 tahun), Staff KPLP, wawancara oleh penulis di Lembaga Pemasyarakatan Kelas IIA Watampone, 21 Maret 2018.

${ }^{76}$ Srianthy (32 tahun), Narapidana, wawancara oleh penulis di Lembaga Pemasyarakatan Kelas IIA Watampone, 21 Maret 2018.

${ }^{77}$ Sadria (28 tahun), Staff KPLP, wawancara oleh penulis di Lemabaga Pemasyarakatan Kelas IIA Watampone, 23 Maret 2018.

${ }^{78}$ Sadria (28 tahun), Staff KPLP, wawancara oleh penulis di Lemabaga Pemasyarakatan Kelas IIA Watampone, 23 Maret 2018.

${ }^{79} \mathrm{ST}$. Madina (38 tahun), Narapidana, wawaancara oleh penulis di Lembaga Pemasyarakatan Kelas IIA Watampone, 21Maret 2018. 
Marwan Fadhel Majid

adalah kesadaran diri dari narapidana itu sendiri untuk menjadi pribadi yang bermartabat. Minimnya kesadaran diri narapidana wanita di lapas kelas IIA Watampone tentu saja menjadi kendala untuk memebentuk prilaku bermartabat.

\section{c) Kebersamaan Narapidana Wanita}

Kebersamaan yang dimaksud dalam penulisan ini adalah narapidana wanita selama berada di dalam lapas menjalin hubungan dan kerjasama sesama narapidana wanita sebagai bentuk perwujudan sosial narapidana selama menjalani masa pidananya.Menurut salah satu narapidana wanita kebersamaaan narapidana wanita di lapas terbangun secara alamia melalu rutinitas sehari-hari yang dijalani, akan tetapi untuk narapidana baru memang tidak sekompak narapidana yang sudah lebih dulu berada di lapas, hal ini dikarenakan lingkungan yang baru terlebih lagi tidak jarang narapidana baru kondisi emosionalnya cenderung stabil. ${ }^{80}$

Kebersamaan yang terjalin sesama narapidana wanita dapat kita jumpai pada kegiatan kerjabakti dipagi hari saat mebersihkan blok, saat saling berbagi bekal yang diberikan oleh keluarga yang mengunjungi, ketika bergantian mengasuh balita yang ada di dalam blok, dan sikap perhatian ketika salah satu napi jatuh sakit atau membutuhkan bantuan. ${ }^{81}$

Kondisi emosional dan pisikologi setiap narapidana yang berbeda dan tidak stabil merupakan salah satu kendala yang dihadapi pihak lapas untuk menciptakan kebersamaan sesama narapidana wanita. Dibutuhkan kegiatan-kegiatan positif yang dapat menghilangkan rasa prustasi narapidana wanita sehingga tercipta susana yang nyaman bagi narapidana dalam menjalani masa pidananya. Adapun bentuk kegiatan tersebut dapat berupa konseling, pertandingan yang melatih kekompakan dan kerjasama, atau kegiatan seperti mengembangkan bakat di bidang kesenian misalnya seperti menari, paduan suara, dan bermain alat musik.

\section{PENUTUP}

\section{Kesimpulan}

1. Subtansi peraturan yang berkaitan dengan pemenuhan hak-hak narapidana wanita yakni, Undang-Undang Nomor 12 tahun 1995 tentang Pemasyarakatan, PERMENKUMHAM Nomor 33 Tahun 2015 tentang pengamanan pada lembaga pemasyarakatan dan rumah tahanan, serta Keputusan Menteri Kehakiman Republik Indonesia No.M.02-PK.04.10 Tahun 1990. Hal ini diuraikan ke dalam 4 (empat) bagian yakni: aspek keamanan, kesehatan, keterampilan, dan spiritual. Ke empat aspek tersebut telah dipenuhi oleh pihak lapas sekalipun pada paksanaan belum maksimal. Keempat aspek tersebut di atas telah sejalan dengan tujuan hukum Islam yaitu maqosid Al-syariah.Aspek keamanan sejalan dengan hifz al-nafs, aspek kesehatan hifz al-nafs, aspek

\footnotetext{
${ }^{80}$ A. Nurmala (48 tahun), Narapidana, wawancara penulis di Lembaga Pemasyarakatan Kelas IIA Watampone, 23 Maret 2018.

${ }^{81}$ Nur.Oktaviani. S (28 tahun), Narapidana, wawancara penulis di Lembaga Pemasyarakatan Kelas IIA Watampone, 29 Maret 2018.
} 
keterampilan sejalan dengan hifz al-aql, dan aspek spiritual sejalan dengan hifzh al-din.

2. Kondisi lapas kelas IIA Watampone dibagi menjadi 4 (empat) bagian: Pertama, Pihak lapas kelas IIA Watampone telah menyediakan beberapa fasilitas yang mencakup fasilitas dalam beribadah, mendapatkan perawatan rohani/jasmani, mendapatkan pendidikan/pengajaran, menyampaikan keluhan, mendapatkan bahan bacaan/mengikuti siaran media massa, serta fasilitas dalam menerima kunjungan keluarga/penasehat hukum. Kedua, pelayanan khusus telah dilakukan oleh lapas kelas IIA Watampone, dengan berupaya menghadirkan pegawai wanita dalam hal memberikan pelayanan kepada narapidana wanita dalam aspek keamanan, kesehatan, dan keterampilan. pelayanan khusus belum berjalan maksimal dikarenakan minimnya kuantitas dan kwalitas pegawai wanita dan Ketiga, dalam pemberian pengamanan terhadap napi wanita, pihak lapas kelas IIA Watampone telah menyediakan blok khusus wanita serta pengamanan oleh staf pengamanan wanita. Namun hal tersebut, belum mampu memberikan keamanan maksimal bagi narapidana wanita.Keempat, lapas kelas IIA Watampone telah melakukan pembinaan khusus dalam bentuk pembekalan keterampilan menjahit dan kerajinan tangan.Namun konsep pembinaan yang diberikan berjalan tidak efektif.

3. Kondisi narapidana wanita di lapas kelas IIA Watampone menunjukkan sikap dan perilaku yang cukup berintegritas yang dibuktikan dengan sikap kejujuran, konsisten dan komitmen oleh para narapidana wanita. Selain integritas, narapidana wanita di lapas kelas IIA Watampone juga menunjukkan sikap yang bermartabat dalam berpakaian, meskipun belum memenuhi standar syariat Islam serta cara berkomunikasi yang tergolong sopan. Selain kedua hal tersebut, rasa kebersamaan di antara sesama napi wanita di lapas kelas IIA Watampone, juga terjalin dengan baik. Rasa kebersamaan ini, dapat disaksikan saat napi membersihkan blok lapas secara gotong royong.

\section{Implikasi}

1. Perlu adanya kebijakan regulasi tambahan sebagai bagian dari politik hokum.Regulasi tersebut mencakup pengaturan tentang pembinaan di bidang kesehatan, khususnya regulasi tentang perlunya perlakuan khusus terhadap narapidana wanita yang sedang hamil, sedang menyusui dan memiliki balita.

2. Kondisi lapas kelas IIA Watampone diperlukan adanya pengadaan beberapa fasilitas, penambahan jumlah pegawai wanita, penambahan jenis pelatihan kemadirian, dan renofasi blok khusus wanita harus segara dilakukan agar narapidana wanita di Lapas Kelas IIA Watampone juga dapat terpenuhi hakhaknya sebagai narapidana. 
3. Perlunya penyediaan tenaga ahli konseling/pembinaan psikologi (kejiwaan) dan bentuk-bentuk kegiatan yang dapat mengobati kondisi kejiwaan narapidana wanita di lapas kelas IIA Watampone.

\section{DAFTAR PUSTAKA}

al-Tamimi, Umar, Lembaga Pemafaan sebagai Alternatif Penyelesaian Perkara Pidana Perspektif Hukum Islam, Jurnal Diskursus Islam, Volume 1 Nomor 3, Desember 2013;

Ahmad, Syaikh Musthafa al-Farran, Tafsir Imam Syafi'I Menyelami kedalaman kandungan Al-Qur'an terjh, Ali Sultan dan Fedrian Hasmad, Jilid. 1, Jakarata: Almahira, 2006;

Arikunto, Suharsimi, Prosedur penelitian: Suatu Pendekatan Praktik, Cet. XIII; Jakarta: Rineka Cipta, 2006;

Atmasasmita, Romli, Beberapa Catatan Isi Naskah RUU Pemasyarakatan, Bandung: Rineika, 1996;

Aziz, Abd Amir, At-Ta'zîr Fi Asy-Syari'ati Al-Islamiyah, Mesir: Dar al- Bab alHalabi WA Awladuhu, 1989;

Bakry, Muammar, Fiqih Prioritas: konstruksi Metodelogi Hukum Islam dan Kompilasi Kaidah Prioritas Hukum Islam, Jakarta: Pustaka Mapan, 2009; 
Chazawi, Adam, Pelajaran Hukum Pidana Bagian I, Jakarta: Raja Grafindo Persada, 2002;

Departeman Hukum dan HAM Direktorat Jenderal Pemasyarakatan, Cetak Biru Pembaharuan Pelaksanaan Pemasyarakatan, Jakarta, [t.p], 2008

Dirjen Pemasyarakatan, Bunga Rampai PemasyarakatanPemasyarakatan, Kumpulan Tulisan-Tulisan Baharuddin Surjobroto, Jakarta: [t.p], 2002; 1997

Djamil, Faturrahman, ,Filsafat Hukum Islam, Jakarata: Logos Wacana Ilmu,

Fuady,Munir,Teori-teori Dalam Sosiologi Hukum, Jakarta: Kencana Prenada MediaGroup, 2011; 2000

Hakim, Rahmat, Hukum Pidana Islam: Fiqh Jinayah, Bandung: Pustaka Setia,

Hallaq, Wael, Sejarah Teori Hukum Islam, Jakarta: Raja Grafindo, 2000;

Hamka, Tafsir Al-Azhar,Jilid10, Jakarta: Pustaka Panjimas, 1998;

Ishaq, Abu, Ibrahim al-Syatibi, al Muawafaqat fi Usl al Ahkam, Juz. 2. Beirut: Darl al Ma'rifah, [t.th.];

Muhammad bin Yazīd Abū'Abdillah al-Qazwain̄̄, Sunan ibnu Mājah, Bairūt: Dār al-Fikr, [t.th]

Munajat, Markhus, Reaktualisasi Pemikiran Hukum Islam, Yogyakarta: Cakrawala, 2006

------, Hukum Islam di Indonesia, Yogyakarta: Bidang Akademik UIN Sunan Kalijaga, 2008

Muslim bin al-Hajjāj Abu al-Husain al-Qusyairiāl-Naisābūri, Șahih Muslim,Bairūt: Dār Ihyā al-Turāंs al-'Arabī, [t.th];

Nawawi, Barda Arief, Pidana Penjara Terbatas: Suatu Gagasan Penggabungan Antara Pidana Penjara Dengan Pidana Pengawasan, Jakarta: Raja Grafindo Persada, 2002.

Raharjo, Stipjo, Ilmu Hukum, Bandung: Citra Aditya Bakti, 2005;

Republik Indonesia , Keputusa Menteri Kehakiman Republik Indonesia No. M. 02-PK.04.10 Tahun 1990;

Republik Indonesia, Undang-undang Nomor 12 tahun 1995 Tentang Pemasyarakatan

Republik Indonesia, Peraturan Pemerintah Republik Indonesia No 32 tahun 1999 Tentang Syarat dan Tata Cara Pelaksanaan Hak Warga Binaan Pemasyarakatan;

Republik Indonesia,Permenkumham 33 Tahun 2015 Tentang Pengamanan Pada Lapas dan Rutan;

Ritongga, A. Rahman, Ensiklopedi Hukum Islam, Jakarta: Ikhtiar Baru Van Hove, 1997

Santoso, Topo, MenggagasHukum Pidana Islam, Bandung: Asy-Syaamil Press \& Grafika, 2000;

Sihab, M. Quraish, Tafsir AL-Misbāh Pesan, Kesan dan Keserasian Al-Qur'an, Cet. III, Jakarta: Lentera Hati, 2005;

Soegono, Bambang, Metodologi Penelitian Hukum, Jakarta: Raja Grafindo Persada, 2007;

Wijaja, Abdi, Penerapan Hukum Pidana Islam Menurut Mazhab Empat (Telaaah Konsep Hudud), [t.t]: Alauddin University Prees, [t.th] 
Tinjauan Hukum Islam terhadap Perlindangan Hukum Narapidana Wanita ... Marwan Fadhel Majid 